\title{
AXIOMS OF VALUE
}

\author{
Reber, Michael (1); Duffy, Alex (2); Hay, Laura (2) \\ 1: Siemens Industry Software GmbH \& Co; 2: University of Strathclyde
}

\begin{abstract}
Extensive work exists on value in multiple domains. However, there are different interpretations, highlighting a lack of clarity about the fundamental characteristics. To address this, we present seven value axioms resulting from inductive research. The axioms may be viewed as general rules describing value in any context, therefore conveying the fundamental characteristics of the phenomenon. They reveal that value is: (1) connected to people; (2) an output of a cognitive process; (3) in requirement of a determination process; (4) a matter of a given situation; (5) determined by the interpretations of entities; and related to (6) entities and (7) criteria. The nature of value is of particular importance to the design community, given the emphasis on value in design and product development. In this context, a lack of clarity may be perceived in terms of when value appears, appropriate metrics, and how to add value. To provide explanations, there is a need for a theory of value in design. The presented axioms may provide the basis, as they are fundamental statements on the nature of value and not limited to a specific domain. We highlight theory requirements based on the axioms.
\end{abstract}

Keywords: Value, Design theory, Design management, New product development

\section{Contact:}

Hay, Laura

University of Strathclyde

Design, Manufacture and Engineering Management

United Kingdom

laura.hay@strath.ac.uk

Cite this article: Reber, M., Duffy, A., Hay, L. (2019) 'Axioms of Value', in Proceedings of the 22nd International

Conference on Engineering Design (ICED19), Delft, The Netherlands, 5-8 August 2019. DOI:10.1017/dsi.2019.222 


\section{INTRODUCTION}

The creation and perception of value is central to the product development process and organisational success. Traditional interpretations of value in a design context have focused on product worth and cost from a manufacturer's perspective (Miles, 1966). However, due to issues such as increased globalisation, lack of sustainability, and the high rate of technological development, these early interpretations have shifted towards a broader conception of value that includes the customer's perspective in terms of benefit, need, quality, utility, and value of services.

Value has been studied extensively in a multitude of domains. Theories of value can be classified with respect to axiology, referring to general or philosophical theories of value (Holbrook, 1994; Lamont, 1956; Rescher, 1982), as well as scientific theories including economics (Allingham, 1982; Bailey, 1967; Borja de Mozota, 2006; Smith, 1904), psychology (Bretano, 1968; Maslow, 1943; Rescher, 1982; Schwartz, 2006), and sociology (Allport, 1961; Feather, 1975; Kluckhohn, 1951; Kohlberg, 1983; Neumann, 1986; Pauls, 1990; Rokeach, 1973; Schwartz and Bilsky, 1987). According to Seni (2007), value theories vary in breadth and level of generality, whereby philosophical theories are seen as the more general and scientific theories as the more specific. They also vary as to the kind of questions they answer. Axiological or so-called general or philosophical theories of value have a focus on what is 'good' and how to evaluate it. Scientific value theories in economics focus on: how to develop, produce, exchange, and distribute valuable products; what imparts goodness to a product, utility, and/or quality; and what makes a product effective, efficient, and/or flexible. In psychology, value theories focus on how individuals develop, believe, assert, and act on values. Sociology on the other hand has a focus on how values are held in society and become aspects of culture and institutions. A considerable body of literature also exists on value in the context of design, and the broader processes of product development and business. Here, numerous types of value are defined. These include brand value (Jones, 1994), customer value (Andriessen, 2003), economic value (Amit and Zott, 2001), exchange value (Sparks et al., 2001), product value (Hamilton, 1996), process value (Amit and Zott, 2001), relationship value (Wilson and Jantrania, 1993), and shareholder value (Doyle, 2000). Additionally, authors make reference to a range of related phenomena including:

- $\quad$ attractiveness (Best and De Valence, 1999);

- $\quad$ availability (Allingham, 1982);

- $\quad$ benefit (Anderson et al., 1993; CABE, 2001; Thomson et al., 2003);

- $\quad$ cost (Ashworth and Hogg, 2000; Berry and Yadav, 1996; Best and De Valence, 1999; British Standards Institution, 2000; Dell'Isola, 1997; Doyle, 2000; Fowler, 1990; Hamilton, 1996; Miles, 1966; Miles, 1972);

- $\quad$ exchange (Allingham, 1982; Anderson et al., 1993; Ashworth and Hogg, 2000; Best and De Valence, 1999; CABE, 2001; SAVE International, 2007);

- $\quad$ need (British Standards Institution, 2000);

- $\quad$ price (Anderson et al., 1993; Chase, 1990; Daniels, 2000;Gale, 1994; Womack and Jones, 1996; Zeithaml 1988);

- $\quad$ quality (Daniels, 2000; Dell'Isola, 1997; Gale, 1994; Grönross, 1997; Zeithaml, 1988);

- $\quad$ scarcity (Ashworth and Hogg, 2000); and

- $\quad$ worth (Anderson et al., 1993; Ashworth and Hogg, 2000; Best and De Valence, 1999; CABE 2001; Holden, 1999; Madison, 2008; Miles, 1966; Najder, 1975)

Further inspection of the above literature reveals different underlying interpretations of the basic nature of value. For instance, as discussed in Section 2, authors refer to the value of an entity, the act of valuing something, and values as moral principles governing human behaviour. Authors have also highlighted questions about when value appears (Borja de Mozota, 2006), what constitute appropriate metrics of value (Daniels, 2006), and how value can be added (Desbarats, 2006). These different interpretations and perspectives highlight the lack of a clear and unified view on the basic nature of value, despite the considerable body of research that exists on the topic. There is a need to formalise the fundamental characteristics of the phenomenon to provide a common basis for research and more general models and theories of value. Given the increasing emphasis placed on value in design and the broader product development process, this research area is of particular importance to the design community. Knowledge of the basic characteristics of value would provide a foundation for robust scientific research on value in design, facilitating explanations on the appearance, measurement, and creation of value in this context. 
Axioms may be viewed as rules that are objective in their grounding and universal in their applicability (Rescher, 1982). On this basis, value axioms may be interpreted as general rules describing value in any context, therefore conveying the fundamental characteristics of the phenomenon. This paper presents the results of an inductive literature investigation with the aim of determining value axioms that may be utilised as the foundation for developing: (i) a general understanding of value, and (ii) specific explanations on value in the context of design. The research adopts a critical realist perspective on value and its interpretation by humans Bhaskar (1989). To provide initial insights into value, we present the results of a literature review on value interpretations in Section 2. In Section 3, seven value axioms are detailed in the context of the literature from which they were determined. Finally, in Section 4, we summarise the key findings and discuss the implications of the work for research on value in design.

\section{VALUE INTERPRETATIONS}

It can be seen from the body of work cited in Section 1 that value is considered in individual disciplines from different perspectives. Within this literature, three interpretations of value may be identified: (i) the value of an entity; (ii) value as an activity; and (iii) value as an ethic/moral principle. Each interpretation is elaborated below, drawing from publications in the following contexts: axiology (e.g. Lamont, 1956; Madison, 2008; Rescher, 1982); business economics (e.g. Allingham, 1982; Ashworth and James, 2001; Best and De Valance, 1999; Gale, 1994; Harrison, 1998; Hamel and Prahalad, 1989; Larreche, 2000); engineering (e.g. Dell'Isola, 1997; Hamilton, 1996; Miles, 1966; Miles, 1972; SAVE International, 2007; Thomson et al., 2003); marketing (e.g. Amit and Zott, 2001; Andriessen, 2003; Kim and Mauborge, 1999; Kotler, 1972; Porter, 1985; Wilson and Jantrania, 1993); psychology (e.g. Bailey, 1967; Feather, 1982; Hight and Cooper, 2006; Kahle and Timmer, 1983; Rokeach, 1973); and sociology (e.g. Hutcheon, 1972; Klukhohn, 1951; Pepper, 1958; Schwartz, 1994; Schwartz, 2006).

Value of an entity (e.g. Allingham, 1982; Anderson et al., 1993; Andriessen, 2003; Ashworth and James, 2001; Best and De Valence, 1999; Chase, 1990; Daniels, 2000; Doyle, 2000; Fowler, 1990; Grönross, 1997; Hamilton, 1996; Lamont, 1956; Larreche, 2000; Miles, 1972; Najder, 1975; Porter, 1985; Zeithaml, 1988) is based on the underlying assumption that value is seen as a kind of benefit derived from an entity. The term entity is used here as a synonym for physical and non-physical objects. The entity may be seen as a value resource. In design, typical entities may be seen in the design artefact, process, and design per se. Value in this context is typically defined in terms of availability, exchange worth, cost, price, usefulness, and utility.

Value as an activity (Hight and Cooper, 2006; Holbrook, 1994; Zeithaml, 1988) refers to the 'act of valuing.' Value in this context is typically seen as related to preferential judgement (Holbrook, 1994) and decision making processes (Hight and Cooper, 2006). In design, we may consider value as an activity from the perspective of, for instance, a customer valuing a particular product.

Value as an ethic/moral principle (e.g. Bailey, 1967; Feather, 1975; Harrison, 1998; Hight and Cooper, 2006; Holbrook, 1994; Rescher, 1982; Rokeach, 1973; Schwartz, 2006) refers to the principles of right and wrong human behaviour and the 'goodness' or 'badness' of human character. The principles are typically discussed in terms of 'human values,' such as helpfulness, honesty, and loyalty as outlined by Schwartz and Boehnke (2004), and characterized by Griseri (1998) as underpinning the activities of business organisations. From the perspective of design, this interpretation of value may be seen to relate to the concept of a design philosophy - that is, a statement of an organisation's basic beliefs, values, and perspectives on design.

The above discussion demonstrates that there is a lack of clarity regarding the characteristics that are fundamental to value across different contexts and domains. There seem to be two different approaches with respect to value interpretations: authors such as Allingham (1982) and Best and De Valence (1999) describe value in the context of properties, while authors such as Holbrook (1994), Hamilton (1996) and Harrison (1998) describe value in the context of cognitive processes. Value as an inherent property of an entity makes the assumption that value exists within a product or activity. Inherent to value as an apprehended property of an entity is the assumption that value is held in the mind in context with an entity. It is not clear from the existing literature if or how the above three interpretations of value are related, or which of the two approaches to conceptualising it is most appropriate. In Section 3, we present the seven value axioms contributed by our research as a means to provide greater clarity in this area. 


\section{VALUE AXIOMS}

As noted in Section 1, axioms may be viewed as rules that are objective in their grounding and universal in their applicability (Rescher, 1982). On this basis, value axioms may be interpreted as general rules describing value in any context, therefore conveying the fundamental characteristics of the phenomenon. Seven value axioms are presented in the following sub-sections. These were identified through inductive research based on the same body of research reviewed in Section 2. Each axiom is outlined in turn below, in the context of the literature from which it was determined.

\subsection{The person axiom}

In the context of research on human values, Rokeach (1973) postulates that one may say that an object possesses value and that a person has value. He suggests that for value research, it may be important to decide whether a systematic study of value will focus on the values that persons are said to have or on values that objects are said to have. Feather (1975) concludes that Rokeach's distinction between the values of a person and an object may not be adequate: value relates to persons and objects, while values involve the person engaged in valuing and an object that is being valued. From Feather's perspective, values do not exist independently of persons and objects.

The result of the investigation supports the concept that value does not exist independently of a person. It is a person that apprehends the value of entities (Lamont, 1956; Miles, 1972; Najder, 1975, Allingham, 1982; Porter, 1985; Zeithaml, 1988, Chase, 1990; Fowler, 1990; Anderson et al., 1993, Hamilton, 1996; Grönross, 1997; Best and De Valence, 1999; Larreche, 2000; Daniels, 2000; Doyle, 2000; Ashworth and James, 2001; Andriessen, 2003); a person that values as an activity (Hight and Cooper, 2006; Holbrook, 1994; Zeithaml, 1988); and a person that holds values in the sense of ethic/moral principles (Bailey, 1967; Feather, 1975; Harrison, 1998; Hight and Cooper, 2006; Holbrook, 1994; Rescher, 1982; Rokeach, 1973; Schwartz, 2006). Engineers focus on the creation of product value (Ashworth and Hogg, 2000; Fowler, 1990; Hamilton, 1996); economists analyse the value of an enterprise (Andriessen and Tissen, 2000; Copeland et al., 2000); and industrialists express their understanding of value in terms of business ethic principles (Hug, 2003). Some definitions utilise a consumer (Burns and Woodruff, 1992; Zeithaml, 1988), customer (Allingham, 1982; Andriessen, 2003; Ashworth and Hogg, 2000), and human being (Bailey, 1967; Best and De Valence, 1999; Fowler, 1990; Hamilton, 1996; Holbrook, 1994; Najder, 1975; Rokeach, 1973), while others utilize an enterprise (Allingham, 1982; Ashworth and Hogg, 2000; Porter, 1985) and organization (Harrison, 1998). In essence, they all represent humans or groups of humans. It is concluded from the literature, value is based on people:

The people axiom: Value is people-based (Axiom 1)

\subsection{The cognition and determination axioms}

As conveyed in Section 2, two questions that are fundamental to value research are: 'Is value a property of entities?' or 'Is it a cognitive determination?' This issue is a matter of on-going debate in literature and despite the research effort that has been expended on the value phenomenon, there is as yet no agreed upon answer.

A source of contention in defining the value phenomenon can be seen in three different research approaches as mentioned by Lamont (1956): approaching value in terms of characteristics an entity has in itself, such as value made up of cost, time, and quality according to Atkin (1990); approaching value in terms of characteristics an entity is said to possess only when an entity is in relation to some other entity, such as asset exchange value according to Sparks et al. (2001); and indicating value as a state of mind in appreciating an entity in terms of ethic/moral principles, such as value as a belief according to Rokeach (1973). The current position in research is one of stalemate.

To overcome the contention with current research approaches, we can refer to Lamont (1956) who suggests an alternative approach for investigating the value phenomenon. Instead of starting with the assumption that value is 'something' (e.g. a property or a relation) and then inquiring about its status in an objective order, we can start with the assumption that in attributing value, this attribution is an activity occurring within the human mind. We can then analyse the nature of this activity. On this second approach, the issue is not one concerning the status of value, but one concerning the nature of the process of value determination. Lamont's approach provides a basis common to all parties to the 
controversy: The acceptance is that, whether value is an intrinsic property or not, there is a cognitive process involved in value determination. From this, the second axiom is introduced:

The cognition axiom: Value is an output of a cognitive process (Axiom 2)

People express value in terms of a statement such as, 'A is of value.' The statement may be seen as an output of a cognitive process. To formalise a value statement requires value determination, i.e. a cognitive process of establishing value aiming towards a value statement. The process per se may be conscious or unconscious, but without such a process, value is not revealed and cannot be consciously derived. Consequently, the following axiom can be introduced:

The determination axiom: Value requires determination (Axiom 3)

The results of a review on value from the perspective of value interpretations, presented in the previous section, provide supporting evidence for the cognition and determination axioms: Bailey (1967) and Rescher (1982) argue that value denotes an effect produced in the mind; Rokeach (1973) and Schwartz (2006) conclude that values are beliefs, i.e. held in the mind; Ehrenfels $(1887 ; 1896$; 1907) saw the foundation of value in desire; Harrison (1998) concludes that value is a concept of what an individual regards as desirable; and Hamilton (1996) argues that value is the level of importance that is placed upon a function, item, or solution. Holbrook (1994) concludes that value refers to a preferential judgement, while values refers to the criteria by which such judgements are made. All of these interpretations refer to value as cognitive concepts, i.e. an effect produced in the mind, belief, desire, level of importance, and criteria by which judgements are made, providing support for the cognition axiom. The interpretation of Holbrook (1994) looking at value as a preferential judgement may be seen as highlighting the determination process of value and supporting the determination axiom.

\subsection{The situation and interpretation axioms}

Research on situated cognition claims that every human thought and action is adapted to the environment where it is situated, because what people perceive, how they conceive their activity, and what they physically do all develop together. What a person brings to a situation comes from their knowledge and understanding (Clancey, 1997). The term knowledge as applied in this article refers in a broad sense to basic physical needs, derivative desires, experiences, expert knowledge, implicit theories on how the physical world behaves, inborn qualities, outcome foci, and self-esteem needs. For example in design, it is this background that distinguishes the design agent's thoughts and actions from one another when they witness or are subject to a given situation. The term understanding as applied in this article refers to the ability to perceive the intended meaning of words (Oxford English Dictionary, 2009). For instance in design, Gero and Kannengiesser (2004) approach situatedness by introducing three different kinds of environments that interact with one another:

- The external world is composed of representations outside an agent; it is the part of the overall environment an agent is aware of. Agents in this sense are autonomous, embodied, engaged, specific, and social: autonomous in that each agent decides by itself what action to take; embodied in that actions by the agent are part of a dynamic with the world and result in sensory feedback; engaged in that they have on-going interactions with the environment; specific in that actions by the agent constrain its behaviour and provide a context within which one reasons and acts; and social in that they are located in a society of agents (Wilson and Keil, 1999).

- The interpreted world exists inside of an agent in terms of sensory experiences, perceptions, and concepts, i.e. it is the internal representation of that part of the external world that the designer interacts with.

- The expected world is the world that imagined actions will produce; it is the environment in which the effects of actions are predicated according to current goals and interpretations of the current state of the world; the expected world is located within the interpreted world.

According to Gero and Kannengiesser (2004), these three worlds are recursively linked together by three classes of processes: (i) transforming the interpretation of variables sensed in the external world into the interpretation of sensory experiences, perceptions, and concepts that compose the interpreted world; (ii) focusing on some aspect of the interpreted world as goals in the expected world and suggesting actions, which if executed in the external world should produce states that reach the goals; and (iii) action as an effect that brings about a change in the external world according to the goals in the expected world. The different environments connected to one another form the situation consisting 
of both the person's external and interpreted worlds. The dynamics of the situation stem from the interaction of the external, interpreted, and expected worlds. Potentially, every change in one of the worlds brings about and is brought about by changes in another world.

Value, as outlined above, is an output of human thought in terms of a cognitive process and consequently it is concluded that value is subject to situatedness:

The situation axiom: Value is subject to situatedness (Axiom 4)

To model situatedness in terms of world views not only provides insights on the situated characteristic of value, but also provides an opportunity to derive two further conclusions on the phenomenon. The first is based on the assumption that agents interpret entities in the external world. Consequently, value is determined on interpreted entities rather than on entities of the external world, since agents cannot bypass the interpretation process. Secondly, if value determination of an entity in the external world is based on an entity's interpretation, this suggests that the principles of value determination for both external and interpreted world entities are the same. The determination process in each situation is based on an entity's interpretation. Consequently, the following axiom is derived:

The interpretation axiom: Value is subject to interpretation (Axiom 5)

The different interpretations of value presented in section two provide supporting evidence for the situation and interpretation axioms per se, in that authors from different disciplines can be seen as interpreting value according to their individual situations and interpretations. The literature provides further evidence for the situation and interpretation axioms: Harrison (1998) argues that value is defined as a concept of what an individual regards as desirable; it may be argued that desire is dependent on the individual situation and interpretation. Allingham (1982) concludes that the value of an asset is defined as a function of usefulness and availability, i.e. two variables dependent on situation and interpretation. Ashworth and Hogg (2000) argue that value is influenced by the conditions of supply and demand, i.e. dependent on situation. Miles (1966) argues that value is the relationship of product worth to product cost, which in turn can be seen as dependent on situation and interpretation. Womack and Jones (1996) and Chase (1990) argue that value is a capability provided to a customer at the right time at an appropriate price, as defined in each case by the customer; the 'right time' and the 'appropriate price' are dependent on the customer's situation and interpretation. Hamilton (1996) concludes that value is the level of importance that is placed upon a function, item, or solution; this level of importance can be seen as dependent on situation and interpretation. Finally, Holbrook (1994) concludes that value refers to a preferential judgement while values is used to refer to the criteria by which such judgements are made. It can be argued that preferential judgements are dependent on situation and interpretation - these are criteria by which such judgements are made.

\subsection{The entity and criteria axioms}

So far, it has been an underlying assumption that value is related to entities because it needs to be the value of 'something.' This assumption is supported by the different value approaches provided in literature in terms of the value of an entity, as an activity, and in the sense of an ethic/moral principle. Lamont (1956) argues that value is based on the characteristics of an entity and on those characteristics an entity is said to possess only when it is in relation to some other entity. In the context of value as an activity, it can be argued that 'valuing' requires 'something' to be valued. Finally, in the context of value as an ethic/moral principle, this principle represents entities per se to which value is ascribed (e.g. the value of honesty or the person who holds the values). In each case, value is related to an entity. In design, typical entities may be seen in the design artefact, process, design per se, and/or design management as entities "valued" by agents.

Considering value definitions from the perspective of people involved (Table 2) serves to illustrate value referring to entities in terms of assets (Allingham, 1982; Best and De Valence, 1999), end-states of existence (Rokeach, 1973), events (Najder, 1975), exchanges (Allingham, 1982; Anderson et al., 1993), functions (Hamilton 1996), items (Hamilton, 1996), modes of conduct (Rokeach, 1973), objects (Bailey, 1967; Najder, 1975), products (Burns and Woodruff, 1992; Miles, 1966), qualities (Najder 1975), solutions (Hamilton, 1996), things (Najder, 1975), and 'what is regarded as desirable' (Harrison 1998). The entities are physical (e.g. products) or non-physical (e.g. exchanges) in nature. Numerous definitions refer explicitly to entities (Allingham, 1982; Anderson et al., 1993; Bailey, 1967; Best and De Valence, 1999; Burns and Woodruff, 1992; Hamilton, 1996; Harrison, 1998; Najder, 1975; 
Rokeach, 1973). Other definitions do not refer explicitly to entities, but the entities can be derived from the interpretation of the definition's context (Ashworth and Hogg, 2000; Cather et al., 2001; Chase, 1990; Fowler, 1990; Porter, 1985; Zeithaml, 1988). Cather et al. (2001) for example, define value as a capability provided to the customer at the right time at an appropriate price, as defined in each case by the customer in the context of product development. Thus, the definition is interpreted as referring to a 'product.' From this it is concluded that value is of 'something,' and is therefore related to an entity:

The entity axiom: Value is entity-connected (Axiom 6)

Another aspect illustrated by considering value definitions from the perspective of people involved is that value definitions incorporate criteria ranging from economic criteria, such as 'low price' (Zeithaml, 1988), 'cost of production' (Ashworth and Hogg, 2000), and the 'amount buyers are willing to pay' (Porter, 1985), to human criteria, such as 'desirability' (Harrison, 1998), 'level of importance' (Hamilton, 1996), and 'personally and socially preferable' (Rokeach, 1973). All value definitions utilise at least one criterion suggesting criteria to be a key element of the value phenomenon. This is supported by Zeithaml (1988), who argues that values refer to the criteria by which judgments are made, and Schwartz (2006), arguing that values serve as standards or criteria:

\section{The criteria axiom: Value is criteria-connected (Axiom 7)}

Finally, it should be recognised that some of the criteria are measurable and others are not. This may be seen as related to the on-going debate in value research on the tangible or intangible nature of value in that intangible value refers to non-measurable criteria (e.g. value in the sense of ethic/moral principles), while tangible value refers to measurable criteria (e.g. value in terms of cost). Furthermore, the measurable criteria may provide a basis to prove or improve value.

\section{CONCLUSION AND FUTURE IMPLICATIONS}

A considerable body of research has been conducted on value across multiple domains. Within this body of work, different interpretations of value may be identified: value of an entity, as an activity, and as an ethic/moral principle. Fundamentally, two approaches to value interpretations exist: value described in the context of properites, and the context of cognitive processes. This highlights a lack of clarity regarding the fundamental characteristics of value. There is a need to formalise these characteristics, to provide a clearer view on the phenomenon and provide a common basis for research. To address this issue, we have presented a set of seven value axioms determined through inductive research based on literature from the following contexts: axiology, business economics, engineering, marketing, psychology, and sociology. The axioms may be viewed as general rules describing value in any context, therefore conveying the fundamental characteristics of the phenomenon. They reveal that value is:

- $\quad$ connected to people (Axiom 1);

- $\quad$ an output of a cognitive process (Axiom 2);

- $\quad$ in requirement of a determination process (Axiom 3);

- a matter of a given situation (Axiom 4);

- determined by the interpretations of entities (Axiom 5); and is

- related to entities (Axiom 6) and to criteria (Axiom 7).

In summary, value is determined and characterised as the output of a cognitive process, subject to situatedness and interpretation, and related to people, entities, and criteria. It can be defined as: $a$ judgement on the extent an interpreted entity satisfies an agent's value criteria.

The nature of value is of particular importance to the design research community, given the emphasis on value in design and the broader product development process. In this context, a lack of clarity on the value phenomenon may be perceived from several perspectives. For instance, Borja de Mozota (2006) states that value happens by achieving a result superior to that of the competitor. Daniels (2006) suggests evaluating the money a design saves in product cost over the previous design and other value metrics such as innovation, differentiation, and simplification. Desbarats (2006) suggests the use of market share as a metric to measure how designs add value. These statements raise three salient questions for research on value in design: when does value appear; what is an appropriate metric for value in design; and how can value be added in design? Without clear answers to these 
questions, it remains difficult for designers to design a 'valuable' product and for customers to distinguish valuable from non-valuable. Thus, there is a need for a scientifically rigorous theory of value in design, to provide explanations in the above areas (and others).

The value axioms provided here are fundamental statements on the nature of value, in that they are neither specialised nor limited to a particular area or domain. The application of the axioms within a particular context does not change the axiom. As such, they may provide the basis for an underlying theory of value in design. The axioms suggest a number of requirements that may need to be fulfilled by any such theory developed through future research:

- The person axiom (Axiom 1) indicates that value is connected to people. A theory of value in design may therefore require a means to reflect the personal characteristics of the value phenomenon.

- The cognition axiom (Axiom 2) and the determination axiom (Axiom 3) indicate that value is an output of a cognitive process, and that a value statement requires a determination process. A theory of value in design may therefore require further explanations on the value determination process.

- The situation axiom (Axiom 4) indicates that value is a matter of a given situation. The interpretation axiom (Axiom 5) indicates that value is determined on the interpretation of entities rather than on entities per se. A theory of value in design may therefore require a means to provide explanations on the situated and interpreted natures of value.

- The entity axiom (Axiom 6) and the criteria axiom (Axiom 7) point to the nature of value to be connected to entities and criteria. A theory of value in design may therefore be expected to provide explanations on the relationship among entities, criteria, and value.

\section{REFERENCES}

Allingham, M. (1982), Value, St. Martin's Press, New York.

Allport, G.W. (1961), Pattern and growth in personality, Holt, Reinhart and Winston, Oxford.

American Marketing Association (2012), Resource library - Dictionary. http://www.marketingpower.com/_layouts/Dictionary.aspx?dLetter=B (Accessed 31 July 2012)

Amit, R. and Zott, C. (2001), "Value creation in E-Business", Strategic Management Journal, Vol. 22, pp. 493-520.

Anderson, J.C., Jain, D.C. and Chintagunta, P.K. (1993), "Customer Value Assessment in Business Markets: State-of-Practice Study", Journal of Business-to-Business Marketing, Vol. 1 No. 1, pp. 3-30.

Andriessen, D. and Tissen, R. (2000), Weightless wealth: find your real value in a future of intangible assets, Financial Times Prentice Hall, London.

Andriessen, D. (2003), Value Based Knowledge Management, Addison Wesley Longman, Amsterdam.

Ashworth, A. and Hogg, K. (2000), Added value in design and construction, Person Education Limited, Singapore.

Ashworth, G. and James B. (2001), Value Based Management, Delivering superior shareholder value, Financial Times Prentice Hall, Englewood Cliffs New Jersey.

Atkin, B. (1990), Information Management of Construction Projects, T.W. Crow Associates, Sydney.

Bailey, S. (1967), A critical dissertation on the nature, measures and causes of value, A. M. Kelley, New York.

Berry, L.L. and Yadav, M.S. (1996), "Capture and communicate value in the pricing of service", Sloan Management Review, Vol. 37 No. 4, pp. 41-51.

Best, R. and De Valence, G. (1999), Building in Value, Arnold Publishing, London.

Bhaskar, R. (1989), Reclaiming reality: A critical introduction to contemporary philosophy. Verso, London.

Borja de Mozota, B. (2006), "The Four Powers of Design: A Value Model in Design Management", Design Management Review, Vol. 17 No. 2, pp. 44-53.

Brentano, F. (1968), The Origin of Our Knowledge of Right and Wrong, Translated by RM Chrisholm and EH Schneewind, Clarendon Press, Oxford.

British Standards Institution (2000), BS EN ISO 9000 Quality management Systems. Fundamentals and Vocabulary, BSI, London.

Burns, M.J. and Woodruff, R.B. (1992), "Delivering Value to Consumers: Implications of Strategy Development and Implementation", In: Allan, C.T. et al. (Eds), Marketing Theory and Applications, American Marketing Association, Chicago, pp. 209-216.

CABE (2001), The Value of Urban Design: A Research Project Commissioned by CABE and DETR to Examine the Value Added by Good Urban Design, Thomas Telford, London.

Cather, H., Morris, R., Philip, M. and Rose, C. (2001), Design Engineering, Butterworth Heinemann, Oxford. 
Chase, J.P. (1990), Value Creation in the Product Development Process, MSc., Massachusetts Institute of Technology.

Clancey, W.J. (1997), Situated Cognition on Human Knowledge and Computer Representations, Cambridge University Press, Cambridge.

Copeland, T., Koller, T. and Murrin, J. (2000), Valuation; Measuring and Managing the Value of Companies, John Wiley \& Sons Inc, New York.

Crosby, L.A. (1990), "Relationship quality in service selling: an interpersonal influence perspective", Journal of Marketing, Vol. 15 No. 3, pp. 68-81.

Daniels, S. (2000), “Customer Value Management”, Work Study, Vol. 49 No. 2, pp. 67-70.

Daniels, G. (2006), "Leveraging Design at Hewlett-Packard in Profiting by Design”, Design Management Review, Vol. 17 No. 2, pp. 57-58.

Dell'Isola, A. (1997), Value Engineering: Practical Applications for Design, R. S. Means Company Inc, Kingston.

Desbarats, G. (2006), “How Does Design Add Value?’ Design Management Review, Vol. 17 No. 2, pp. $56-57$.

Doyle, P. (2000), Value Based Marketing: Marketing Strategies for Cooperate Growth and Shareholder Value, John Wiley \& Sons Ltd, Chichester.

Ehrenfels, v.C. (1887), “Über Fühlen und Wollen”, Sitzungsbericht der Kaiserlichen Akademie der Wissenschaften, Vol. 114, pp. 523-636.

Ehrenfels, v.C. (1896), "Von der Wertdefinition zum Motivationsgesetz", Archiv für systematische Philosophie, Vol. 1, pp. 433-456.

Ehrenfels, v.C. (1907), Grundbegriffe der Ethik, 56, Suhrkamp Verlag, Frankfurt am Main.

Feather, N.T. (1975), Value in Education and Society. The Free Press, New York.

Feather, N.T. (1982), Expectations and Actions: Expectancy Value-Models in Psychology, Lawrence Erlbaum Associated Publisher, New Jersey.

Fowler, T.C. (1990), VA in Design, Van Nostrand Reinhold, New York.

Gale, B.T. (1994), Managing Customer Value: Creating Quality and Service That Customers Can See, The Free Press, New York.

Gero, J.S. and Kannengiesser, U., 2004. The situated function-behaviour-structure framework. Des. Stud., Vol. 25, pp. 373-391. http://dx.doi.org/10.1016/j.destud.2003.10.010

Griseri, P. (1998), Managing Values: Ethical Changes in Organisations, MacMillan Business, London.

Grönross, C. (1997), "Value-driven relational marketing: from products to resources and competencies", Journal of Marketing Management, Vol. 13, pp. 407-419.

Gummerson, E. (1999), Total Relationship Marketing, Butterworth-Heinemann, Oxford.

Hamel, G. and Prahalad, C.K. (1989), "Strategic Intent", Harvard Business Review, Vol. 72 No. 6, pp. $79-88$.

Hamilton, A. (1996), Creating Value in Engineering, Thomas Thelford Publishing Ltd, London.

Harrison, E. (1998), The Managerial Decision-Making Process, Haughton Mafflin Company, Boston.

Hight, D.L. and Cooper, D.L. (2006), Communicating for Character: Designing Community Value Statements, Journal of College and Character, Vol. 5 No. 7, pp. 1-20.

Holbrook, M.B. (1994), “The Nature of Customer Value”, in Rust, R.T. and Oliver, R.L. (Eds), Service quality: New Directions in Theory and Practice, Sage, Thousand Oaks, pp. 21-71.

Holden, J. (1999), Power Base Selling, John Wiley \& Sons Ltd, New York.

Hug, C. (2003), Investigation on current understanding of value in mechanical engineering companies, Berufsakademie Mosbach, Mosbach.

Hutcheon, P.D. (1972), "Value Theory: Toward Conceptual Clarification”, The British Journal of Sociology, Vol. 23, pp. 172-187.

Jones, G., 1994. Adding Value; Brands and Marketing in Food and Drink. Routledge, London.

Kahle, L.R. and Timmer, G. (1983), “A theory and a method for studying values”, Journal of Food Quality and Preference, Vol. 4, pp. 11-20.

Kim, C.W. and Mauborge, R. (1999), Diagnosing and Changing Organisational Culture, Addison Wesley Longman, Harlow.

Kluckhohn, C. (1951), Values and value-orientations in the theory of action: an exploration in definition and classification, Harvard University Press, Cambridge.

Kohlberg, L. (1983), Moral stages: a current reformulation and a response to critics, Karger, Basel.

Kotler, P. (1972), “A Generic Concept of Marketing”, Journal of Marketing, Vol. 36, pp. 46-54.

Lamont, W.D. (1956), The Value Judgement, University Press, Edinburgh.

Lappierre, J. (2000), "Customer-perceived value in industrial contexts", Journal of Business and Industrial Marketing, Vol. 15, pp. 133-140.

Larreche, J.C. (2000), "Cooperate Leadership in the New Economy", The Salamander Link, the Magazine of the Insead Alumni Association, January.

Madison, N. (2008), What is value theory? http://www.wisegeek.com/what-is-value-theory.html (Accessed 3 March 2008).

Maslow, A.H. (1943), “A Theory on Human Motivation”, Psychology Review, Vol. 50, pp. 370-396. 
Miles, L.D. (1966), "VA Evaluating the Worth of a Product's Function' in Proceedings of the 1966 S.A.V.E. Symposium Western Electronic Conference, Los Angeles.

Miles, L.D. (1972), Techniques of VA and Engineering, McGraw-Hill, New York.

Najder, Z. (1975), Values and Evaluations, Clarendon Press, Oxford.

Neumann, K. (1986), Personal values and commitment to energy conservation, Environment and Behaviour, Vol. 18 No. 1, pp. 53-74.

Oxford English Dictionary (2009), Oxford English Dictionary, 11th ed., Oxford University Press, Oxford.

Pauls, R. (1990), Concepts of value: a multi-disciplinary clarification, Centre of Resource Management, Lincoln University, Information Paper Nr. 20.

Pepper, S.C. (1958), The source of value, University of California Press, Berkeley.

Porter, M.E. (1985), Competitive Advantage, Creating and Sustaining Superior Performance, Free Press, New York.

Rescher, N. (1982), Introduction to Value Theory, Rowman \& Littlefield, Totowa.

Rokeach, M.J. (1973), The Nature of Human Value, The Free Press, New York.

Sanchez-Ferandez, R. and Iniesta-Bonillo, M. (2008), The concept of perceived value: a systematic review of the research, University of Almeria, Almeria.

SAVE International (2007), Value Standard and Body of Knowledge, Northbrook.

Sayer, A. (1992), Method in Social Science, Routledge, London.

Schwartz, S.H. (1994), “Are there universal aspects in the content and structure of values?” Journal of Social Issues, Vol. 50, pp. 19-45.

Schwartz, S.H. (2006), Basic human values: Theory, measurement, and applications, Hebrew University of Jerusalem, Jerusalem.

Schwartz, S.H. and Bilsky, W. (1987), "Toward a universal psychological structure of human values”, Journal of Personality and Social Psychology, Vol. 53, pp. 550-562.

Schwartz, S.H. and Boehnke, K. (2004), "Evaluating the Structure of Human Values with Confirmatory Factor Analysis", Journal of Research in Personality, Vol. 38, pp. 230-255.

Seni, D.A. (2007), "The technological theory of value: Towards a framework for value management", Value World, Vol. 30 No. 2, pp. 1-15.

Smith, A. (1904), An Inquiry into the Nature and Causes of the Wealth of Nations, Methuen \& Co, London.

Sparks, L., Bargery, R., Billingham, J., Ellis, P. and Strelitz, Z. (2001), Value of Urban Design, Thomas Telford, London.

Teece, D. (1998), "Capturing value from knowledge assets: the new economy, markets for know-how and intangible assets", California Management Review, Vol. 40, pp. 55-79.

Thomson, D.S., Austin, S.A., Devine-Wright, H. and Mills, G.R. (2003), "Managing value and quality in design”, Building Research \& Information, Vol. 31 No. 5, pp. 334-345.

Wilson, D.T. and Jantrania, S.A. (1993), "Measuring Value in Relationship Development", In: Proceedings of the 9th IMP Conference, Bath.

Wilson, R.W. and Keil, F. (1999), The MIT Encyclopedia of the Cognitive Science, MIT Press, Cambridge.

Womack, J.P. and Jones, D.T. (1996), Lean Thinking, Simon \& Schuster, London.

Woodruff, R.B. (1996), Know your customer: new approaches to understanding customer value satisfaction, Blackwell Publisher Inc., Massachusetts.

Zeithaml, V.A. (1988), "Consumer perception of price, quality, and value: a means-end model and synthesis of evidence", Journal of Marketing, Vol. 52 No. 3, pp. 2-22. 